\title{
KONSEP AKAL BERTINGKAT AL-FARABI DALAM TEORI NEUROSAINS DAN RELEVANSINYA DENGAN PENDIDIKAN ISLAM
}

\author{
Ruri Afria Nursa ${ }^{*}$, Suyadi ${ }^{2}$ \\ Universitas Ahmad Dahlan, Indonesia \\ 2 Universitas Ahmad Dahlan, Indonesia \\ "email.afrianursaruri@gmail.com
}

\begin{abstract}
The concept of reason in Al-farabi's view has many similarities with the study of modern neuroscience. For example human potential. Therefore, this study seeks to find descriptively the concept of the level of Al-Farabi theory in neuroscience theory and its relevance to Islamic education. This study aims to find the relevance of Al-Farabi's multilevel perspective perspective in neuroscience. This research method is in the form of library research using a descriptive approach to the analysis of the themes of neuroscience, Al-Farabi-level reasoning, and Islamic education. The results of this study indicate that according to Al-Farabi, reason is divided into three namely God as reason, the intellects in the philosophy of emanation from one to ten, and the reason contained in human beings. This study also has a contribution to Islamic education that is something related to the mind and awareness as an important part of human formation itself is interconnected between the brain and other nerve cells. It can be concluded that the concept of multilevel Al-Farabi's mind originally originated from the mind in which Al-Farabi discussed the intellect that exists in man, the intellect is: potential sense, actual reason, mustafad reason. Whereas the study of reason is neuroscience.
\end{abstract}

Keywords: Al-Farabi; multilevel common sense; neuroscience; islamic education.

\begin{abstract}
ABSTRAK
Konsep akal dalam pandangan Al-farabi memiliki banyak persamaan dengan kajian neurosains modern. Contohnya potensi manusia. Oleh karena itu penelitian ini berupaya menemukan secara deskriptif konsep akal bertingkat Al-farabi dalam teori neurosains dan relevansinya dengan pendidikan Islam. Penelitian ini bertujuan untuk menemukan relevansi pendidikan Islam perspektif akal bertingkat Al-farabi dalam neurosains. Metode penelitian ini berbentuk penelitian kepustakaan menggunakan metode pendekatan deskriptif analisis terhadap tematema neurosains, akal bertingkat Al-farabi, dan pendidikan Islam. Hasil kajian ini menunjukkan bahwa menurut Al-farabi, akal dibagi menjadi tiga yaitu Allah sebagai akal, akal-akal dalam filsafat emanasi satu sampai sepuluh, dan akal yang terdapat pada diri manusia. Kajian ini juga memiliki kontribusi terhadap pendidikan Islam bahwa merupakan sesuatu yang terkait dengan pikiran serta kesadaran selaku bagian penting pembentukan manusia itu sendiri saling berhubungan antara otak dan sel-sel saraf lainnya. Dapat disimpulkan bahwa konsep akal bertingkat Al-farabi awalnya bermula dari batin yang mana Al-farabi membahas akal yang ada
\end{abstract}


pada diri manusia, akal tersebut ialah: akal potensial, akal aktual, akal mustafad. Sedangkan ilmu mempelajari akal adalah neurosains.

Kata kunci : akal bertingkat; Al-farabi; neurosains; pendidikan islam.

\section{Pendahuluan}

Tidak semua kehidupan Al-farabi diketahui kecuali bahwa dia berasal dari kota Atrar (Tranxosiana). Ayah dia seorang tentara Persia dan ibunya berkebangsaan Turkinistan. Oleh sebab itu kadang beliau termasuk kalangan Turkinistan. Namun sesuai keyakinan Islam yang menunjukkan kalangan keluarga ayah, beliau termasuk golongan Persia (Sirajuddin, 2012). Pada usia empat puluh tahun Al-farabi langsung berguru pada sejumlah ahli logika terpandang kala itu, termasuk Abu Bisyr Mattius dan Yuhanna ibn Jailan. Tidak beberapa lama di Mesir, beliau bermukim di sebuah kota Syria, tatkala itu dalam pemerintahan pangeran Hamdan Sayf al-Dawla al-Taghlibi. Sayf al-Dawla sebagai pembesar pemerintah banyak mendukung kegiatan ilmu pengetahuan dan sangat takzim terhadap Al-farabi. Setelah itu, beliau bermigrasi ke Damaskus sampai wafat pada tahun $950 \mathrm{M}$ saat berumur 80 (Majid, 2002).

Al-farabi seorang filsuf sekaligus sufi. Perkembangan sufi era sekarang adalah urban sufisme (sufi yang hidup di kota-kota besar) bukan lagi sufi yang menyendiri. Hal ini disebabkan oleh al-farabi menolak kehidupan soliter yaitu mengucilkan diri sendiri (Majid, 2002). Pemikiran al-farabi terhadap kota mempersatukan utopianisme platonik menggunakan ajaran politik Islam. Sementara teori politik Islam, seorang imam-kahlifah hendaklah memegang hukum syariah yang telah diwahyukan Allah swt sebagai pedoman. Selain dari konsep tentang kota, Al-farabi juga membahas konsep akal bertingkat yaitu Allah sebagai 'aql (daya pikir), 'aql pada filsafat emanasi satu sampai sepuluh, dan 'aql yang ada dalam jiwa seseorang (Sirajuddin, 2012). Setelah membaca buku Al-farabi dengan judul Agrab Kitab ma' Wara' Al-Tabi'ah li Aristu, Ibnu Sina dengan tulus mengakui dirinya sebagai murid yang setia dari Al-farabi.

Ibnu Sina berpendapat bahwa akal menurutnya sebagai kamal al-awwal, karena mampu membagikan keistimewaan pada pemahaman dan segala kemampuan. Ibn Sina mengemukakan nafs sebagai kamal al-awwal, bahwasanya nafs dinilai menjadi pemicu kepada jenis yang tersedia setelahnya untuk menjadi jenis lainnya. Selain yang tertera di atas, pada sebutan Ibn Sina ada jism sina'iy (artifisial).

Selain itu, filosof Muslim dalam memakai kata akal menggunakan dua pengertian ialah akal dalam aliran tasawur dan akal dalam defenisi tasdiq yang dimiliki bagi roh manusia melalui fitrah dengan ilmu yang dihasilkan melalui upaya. Akal yang dimaksudkan dalam melahirkan daya-daya yang dimiliki oleh anggota rohani. Akal ini berawal dari dua anggota rohani manusia. Oleh sebab itu, penjelasan mengenai akal 
merupakan penjelasan al-nafs al-insaniyah yang memiliki daya dan daya tersebut dinamai daya pikir (akal).

Mengenai pemikiran terdahulu sudah pernah dikemukan Al-kindi yang menjadi filosof awal saat ajaran Islam, beliau memakai kata al ajzam, al nufus, dan al 'uqulyang paling kecil klasifikasinya ialah al ajzam dan yang paripurna yakni al 'uqul. Dinyatakan A/ ajzam paling kecil sebab bentuk inilah yang paling belakang saat proses pembentukan sehingga jaraknya amat jauh dari asal wujud. Bentuk ini tiada memiliki daya atas dirinya. Al 'uqul dan al ajzam memiliki sifat yang berlainan serta melahirkan esensi immaterial murni dan berasosiasi atas bentuk-bentuk konseptual. A/ ajzam merupakan esensi immaterial yang sekedar berjiwa pasif, atas kepribadian esensinya yang bergantung antara satu dengan lain, sehingga kedua bentuk ini tidak dapat berkorelasi secara langsung (Al-Kindi, 1950).

Sejauh penelusuran peneliti terhadap berbagai sumber pustaka, belum ditemukan hasil penelitian yang fokus membahas tentang konsep akal bertingkat Al-farabi dalam teori neurosains dan relevansinya dengan pendidikan Islam. Penelitian yang dilakukan oleh Astuti Budi Handayani dan Suyadi dengan judul relevansi konsep akal bertingkat ibnu sina dalam pendidikan Islam. Kajian ini merupakan telaah kepustakaan dengan pendekatan kualitatif deskriptif. Hasil kajian ini menenujukkan bahwa menurut Ibnu Sina, akal itu dibagi menjadi empat tingkat yakni daya materi, daya kemampuan, daya faktual, dan daya penerimaan. Dalam konsep akal bertingkat, Ibnu Sina menyatakan bahwa melalui akal aktif-lah Tuhan itu masuk dalam diri manusia. Akal bertingkat atau hirarki akal yang dari sudut pandang manusia dimulai dari adanya daya material (al 'aql al hayulani), dan daya berakhir pada daya penerimaan (al aql al mustafad) itu menjelaskan bagaimana cara manusia terhubung dengan Tuhan. Terkait dengan pendidikan Islam, dalam pandangan Ibnu Sina, pendidikan itu seharusnya bertujuan untuk menggali dan mengembangkan potensi yang dimiliki oleh peserta didik. Pengembangan potensi itu di antaranya adalah perkembangan fisik, intelektual, dan budi pekerti dalam rangka mewujudkan insan kamil (Handayani \& Suyadi, 2019).

Penelitian yang dilakukan oleh Ahmad Arisatul Cholik dengan judul Relasi Akal dan Kalbu Menurut A/ Ghazali. Menurut al-Ghazali, daya kalbu tidak dapat diputuskan antara satu dan berlainan, sebagaimana khasanah ini tidak dapat diputuskan dari khasanah lain. Kaitan antara daya dan kalbu ini yang kodratnya berupaya membuktikan realitas terhadap individu. Gagasan Al Ghazali, interkoneksi itulah yang ternyata beranjak dari pendapat bersifat sudut pandang jasad sebagai asal sudut pandang spritual individu dalam kerangka kerohanian, dan itu dikelola oleh daya dan kalbu. Penelitian ini mendapatkan hasil yaitu: daya dan kalbu berjiwa lembut dan sopan; daya ekslusif semata-mata pada persoalan intelegensial, sementara kalbu juga menyerap realitas akan tetapi dalam hal antusiasme; kompetensi kalbu berarti menjangkau zona metafisik 
selama didorong oleh keterampilan logis, akan tetapi pengeetahuan tidak sanggup mengelakkan kalbu dari kecacatan melainkan dengan menyerap keterampilan agama melewati petunjuk nabi (Cholik, 2015).

Penelitian yang dilakukan oleh Suyadi dengan judul Integrasi Pendidikan Islam dan neurosains dan Implikasinya Bagi Pendidikan Dasar (PGMI). Penelitian ini berkaitan sebagai teoritis, praktis dan filosofis, menyatakan program studi PGMI mengantongi harapan berkembang sejak rencana integrasi-interkoneksi keahlian, sebab di program studi PGMI seluruh disiplin keahlian dipelajari sebagai holistik-integralistik. Hasil integrasi antara pembelajaran Islam beserta neurosains dalam peneitian ini disebut Neuroscience Islamic Education (Suyadi, 2012).

Dari konsep akal Al-farabi yang ketiga memiliki persamaan dengan kajian neurosain yaitu akal yang terdapat dalam diri manusia. Tatkala manusia dilahirkan ke dunia, akal rohani maupun jasmani memiliki kekuatan bersifat fitrah yang melahirkan kekuatan mantik, otak, pikiran, logika, maupun cara berpikir yang bertambah muluk yang berkenaan atas wawasan, intelek dan kepintaran berpikir. Sebagai kekuatan (daya), ia layak dilatih, diarahkan, dibiasakan, dididik dan ditumbuh kembangkan agar terdaya berpikir atau berproses secara menyeluruh. Di sinilah pelatihan peningkatan akal memegang fungsi relevan demi penyusunan atau rekayasa nalar manusia. llmu yang mempelajari tentang akal dan otak adalah neurosaian (Pasiak, 2006). Menurut Pasiak, neurosains merupakan ilmu neural (neural science) yang mengamati sistem syaraf, lebihlebih mengamati neuron atau sel syaraf menggunakan pendekatan dengan berbagai disiplin ilmu (Pasiak, 2012). Sedangkan, Al-farabi memandang akal atau otak memiliki dua manfaat yaitu: memanfaatkan pancaindra melalui sistem syaraf agar memperoleh tanggapan secara konkret, serta memanfaatkan urat untuk bekerja merespon debar jantung (Majid, 2002). Sedangkan ilmu neurosain berupaya akan mencerna tingkah laku manusia melalui mengkaji komponen-komponen biologisya. Rahasia intens ilmu neurosains ialah seluruh yang terikat pada otak manusia, juga korelasinya pada kesadaran menjadi komponen kunci pembentuk ciri-ciri manusia (Taruna, 2015).

Berdasarkan teori di atas konsep akal bertingkat Al-farabi awalnya bermula dari batin yang mana Al-farabi membahas tentang akal yang ada pada diri manusia yang terdiri dari: akal potensial (al-'aql al-hayulany), akal aktual (al-'aql bi al-fi'l) dan akal mustafad (al-aql al-mustafad). Akal potensial ini dalam basis potensi setiap orang punya, pada setiap manusia akan menemukan solusi atau jalan keluar dari suatu masalah karena manusia itu memiliki akal potensial yang ada pada dirinya. Dengan demikian peneliti perlu mengkaji lebih lanjut konsep akal bertingkat Al-farabi dalam neurosaians. Hal ini dikarenakan peran dan keajaiban otak manusia sebagai pusat intelegensi, berpikir, berkesadaran, berinovasi, juga atas fungsi otak sebagai pusat penerjemah pancaindra (Taruna, 2015). Menurut Suyadi seluruh potensi manusia 
bertumpu pada otak (Suyadi, 2012). Otak manusia memiliki energi yang sangat kuat, efisien, yang bisa secara madiri memahami berbagai proses yang terjadi dalam dirinya, dan demikian pula secara mandiri dapat memperbaiki jika terjadi kesalahan. Manusia itu memiliki potensi berpikir yang ada dalam dirinya, tetapi tidak semua manusia yang mampu mengoptimalkan kemampuannya.

Di dalam neurosaians, akal (otak) atau daya pikir dianalisa dari dua bagian ialah sesuai komposisi dan peranan. Bidang neurosains secara unik mengamati peranan dan susunan komposisi dari otak sebagai sisi susunan komposisi yang mengendalikan makhluk hidup. Mengkaji otak berarti mengkaji belahan terakhir dari makhluk hidup yang amat rumit, sebab keterkaitan pada seluruh aspek kehidupan manusia, mulai dari tingkat terkecil hingga tingkat terbesar bahkan perspektif global (Taruna, 2015). Selain itu, ilmu neurosains tatkala dikembangkan, bahwa otak atau daya pikir manusia menyimpan rahasia yaitu kunci kecerdasan, kecendikiaan, kepintaran, kesadaran, kreativitas, berpikir, serta menjadi kunci penyambut informasi panca indra. Apalagi, pemantauan dan regulasi otak mencakup seluruh sistem organ seperti: sirkulasi darah, sirkulasi oksigen melalui pernapasan, usus, paru-paru, ginjal, hati, dan lain sebagainya (Taruna, 2015). Juga dijelaskan bahwa roh (jiwa), hati dan akal (daya pikir) beroperasi dan dinyatakan ada saat otak ("aql) mampu berfungsi selaku normal.

Pasiak menyatakan, ada dua argumen kenapa otak berperan secara signifikan yakni, otak sebagai pusat seluruh kemampuan yang tumbuh pada jasad, di antaranya aktivitas bergerak dan tidak bergerak; menurut ilmuan sekiranya dilihat dari kedudukannya, otak berpengaruh terhadap organ jasad seseorang, hal ini disebabkan otak terletak paling paripurna di antara organ-organ lainnya (Nukman, 2009).

Dalam konteks pendidikan Islam, banyak istilah yang serupa tentang akal yang semakin membingungkan. Istilah-istilah tersebut adalah al-aql (akal), al-qolb (hati), annafs (nafsu, kehendak) ataupun ar-ruh (ruh). Dalam hal ini Taufiq Pasiak dengan tegas menyatakan bahwa istilah al-'aql, al-qolb, an-nafs, ataupun ar-ruh, semua tidak akan bermakna apabila tidak dihubungkan sama sekali dengan otak manusia, karena semua makna tersebut mempunyai basis neurobiologis di dalam otak manusia (Suyadi, 2017b). Menurut Taufiq Pasiak, kata daya pikir bersumber dari bahasa Arab yaitu aqola, ya'qilu, 'aqlan. Ensiklopedi bahasa Indonesia, akal diartikan sebagai daya pikir, daya upaya, tipu daya, tipu muslihat, kecerdikan, kelicikan, serta kemampuan melihat. Sedangkan menurut Syed Muh al Naquib bin Ali Abdullah bin Muhsin al Attas berpendapat jika daya pikir merupakan sel yang hidup dan bergerak, merangsang dan membendung tujuan pengetahuan menggunakan istilah atau kerangka perlambangan lain. Penjelasan di atas menjelaskan fakta yang sama dari yang ditunjukkan oleh al-'aql, al-qolb, an-nafs, dan ar-ruh adalah otak itu sendiri (Suyadi, 2017b). 
Oleh karena itu, tulisan ini akan mengungkapkan konsep akal bertingkat Al-farabi dalam teori neurosains dan relevansinya dengan pendidikan Islam.

\section{Metode Penelitian}

Kajian ini merupakan telaah kepustakaan dengan pendekatan deskriptif analisis (Muhadjir, 2011). Adapun analisis yang diguanakan dalam kajian ini ialah hermeneotik phenemenolojik (Muhadjir, 2011) dengan ketentuan-ketentuan seperti objektif, sistematis dan general. Sumber data penelitian ini adalah buku-buku yang membahas pemikiran Al-farabi, ilmu neurosains modern dan temuan-temuan penelitian atau jurnal yang berkaitan dengan tema neurosains, akal bertingkat dan pendidikan Islam. Termasuk di dalam sumber kajian ini ialah pandangan-pandangan filusuf muslim mengenai akal atau daya, upaya berpikir. Teknik analisis data dilakukan dengan mengklarifikasi, komparasi dan interprestasi terhadap tema-tema pemikiran Al-farabi, neurosains, pendidikan Islam dengan mengguanakan teknik analisis isi.

Pendekatan yang digunakan dalam penelitian ini ialah fenumenoloji dengan menganalisa secara teori digipsum dalam pandangan neurosains. Pendekatan fenumenoloji digunakan agar memahami konsep-konsep jenjang akal dalam pemikiran Al-farabi khususnya. Sedangkan pendekatan neurosain dimanfaatkan sebagai sudut pandang sekalian konsep teoristik. Maksudnya, pemikiran-pemikiran filusuf mengenai akal dilihat dari aspek regulasi mekanisme kinerja di dalam otak. Dengan demikian dapat diketahui apa yang telah terjadi di dalam otak ketika sedang berpikir. Langkahlangkah dalam kajian ini, secara metodologis, langkah-langkah yang dilewati dalam kajian ini ialah: a. mengumpulkan sumber yang berkaitan terhadap akal bertingkat dalam pandangan Al-farabi, khasnya kajian neurosain serta pendidikan Islam. b. Melakukan analisis interstekstualitas secara interfreatif dengan menegaskan pada deskriptif analisis isi, lalu merelevansikan pendidikan Islam dan neurosains suatu faedah yang sempurna. c. Melaksanakan telaah pemahaman probabilitas keterkaitan yang akan muncul apabila teori neurosains direlevansinkan dengan pendidikan Islam.

\section{Hasil dan Pembahasan}

\section{A. Konsep akal bertingkat Al-farabi}

Akal atau daya pikir dalam pandangan filsuf Al-farabi menduduki posisi unik sebagai subyek pengertiannya, termasuk pemikiran metafisika yang berinteraksi atas pembentukan. Persepsi daya pikir ini kuat korelasinya dengan sintesis neurosaians, di mana ilmu neurosains mampu mengungkapkan apa yang ada di otak yang mana di dalamnya terdapat akal. Al-farabi membagi akal secara garis besar menjadi dua yaitu: 
pertama, akal praktis yang berfungsi menyelesaikan hal-hal teknis dan keterampilan; kedua, akal teoritis yang membantu jiwa mendapatkan inspirasi atau ilham. Pembahasan ini hanya dibatasi pada bagian kedua.

Pembagian akal Al-farabi berbeda dengan akal Ibn Sina. Ibnu sina berpendapat bahwa akal menurutnya sebagai kamal al-awwal, sebab berdaya mengasungkan keutuhan pada pemahaman dan berupa keaktifan. Ibn Sina berpendapat bahwasanya jiwa (nafs) selaku kamal al awal, maknanya bahwa jiwa dari tubuh dan ruh diperhitungkan sebagai pemicu bagi jenis-jenis yang ada selepasnya sebagai jenis lain. Selain al kamal tertulis, dalam sebutan Ibn Sina terdapat jism sina'iy (artifisial). Hal ini berbeda dengan akal jasad maupun yang simpel dikatakan Al-farabi serupa daya pikir terpendam yaitu jasad, ruh atau bagian yang memiliki daya mengkonseptual dan menyerap hakikat yang nyata. Daya pikir yang disebut aktivitas atau sesekali yang diucap teratur ialah suatu tingkatan dari gagasan dalam cara mendapatkan kuantitas apresiasi. Sebab gagasan tidak kuasa menangkap segala penafsiran sehingga daya pikir dalam cara nyatalah yang menyebabkan ia merespon. Sedemikian itu, daya pikir berupaya merespon sinopsis, hingga maju ketingkat daya pikir yang diterima yakni satu tingkatan di mana daya pikir jasad mengabstrak struktur yang tidak kuasa memiliki interaksi dengan substansi (Syarif, 1994).

Bagi Al-farabi, ada tiga tingkatan daya pikir (akal) yakni, Allah menjadi daya pikir (akal) (Sirajuddin, 2012). Agustinus berpendapat, kalangan filsuft membahas perbuatan diperoleh 2 anggapan, pandagan beberapa filsuf Yunani lazim mengungkapkan bahwa jagad raya dengan seluruh isinya yang ada bukan diciptakan dari objek terbatas konstruksinya, memisahkan dari kekurangan, Allah sebagai penciptaan dengan tidak menggunakan subjek apapun membeda-bedakan dari kekurangan (Simon, 2004). Menurut Al-farabi Allah merupakan aqola bersih. la Esa adanya dan yang menjadi objek pemikiran-Nya hanya substansi-Nya. Bahwasanya, la tidak membutuhkan sesuatu berlainan untuk menafakurkan esensi-Nya, melainkan pada esensi-Nya. Oleh sebab itu, Allah sebagai 'Aqola (akal), 'Aqiil (substansi yang berpikir), dan Ma'quul (substansi yang dipikirkan) (Al-farabi, 1905). Begitu juga, Allah swt maha mengetahui. la tidak memerlukan sesuatu yang asing dari entitas-Nya untuk mengetahui, apalagi puas dengan esensi-Nya. Allah dalah pengetahuan, entitas yang memahami dan entitas yang dipahami ('Ilmu, 'Alima, dan Ma'luum) (Al-farabi, 1905); daya-daya dalam fillsafat emmanasi: 1 sampai 10 (Sirajuddin, 2012). Mendahului filsafat emmanasi ala Al-farabi, barangkali akan enteng dipahami apabila diamati tahapan pemikiran metafisika neoplatonisme, keduanya memegang interelasi dalam figur pikir. Bagi neoplatonis, daya pikir sebagai bentuk yang nyata terbukti 'menyamai' pencipta dari seluruh jagad raya. Emanasi al-wujud pada pembawaannya berawal dari al-wujud yang pertama dan mereproduksikan al-wujud yang lainnya (Al-farabi, 1905) terbentuk dalam aliran satu- 
satunya dan bertingkatan secara mekanisdeterminis yang mendatangkan jagad raya bermacam corak. Daya sejati berpikir berkenaan pribadinya yang menghasilan bentuk pertama (al-maujud al-awwal) yakni Tuhan menjadi daya pikir (akal) yang berkemampuan terhadap individu-Nya. Dari adanya spekulasi Tuhan yang agung juga luar biasa muncul bentuk kedua yang menggambarkan daya pikir (akal) pertama yang juga memiliki esensi. bentuk kedua atau akal sebagai daya pikir pertama berpikir mengenai individunya dan mencetuskan bentuk bercorak angkasa perdana. Daya pikir (akal) kedua berpikir mengenai Tuhan menghasilkan daya pikir (akal) ketiga, daya pikir yang disebut sebagai akal ketiga berpikir berkenaan Tuhan menghasilkan daya pikir (akal) keempat, dan seterusnya sampai ke daya pikir yang disebut akal kesepuluh, dari kesepuluh daya-daya di atas, berpikir mengenai individunya menghasilkan bentuk substansi berupa langit, bintang, saturnus, yupiter, mars, matahari, venus, merkurius, serta bulan. Untuk lebih jelasnya lihat tabel emanasi Al-farabi di bawah ini (Sirajuddin, 2012):

Tabel 1: emanasi Al-farabi

\begin{tabular}{|c|c|c|c|c|}
\hline \multirow{2}{*}{$\begin{array}{l}\text { Pokok } \\
\text { daya } \\
\text { pikir }\end{array}$} & \multirow[b]{2}{*}{ Ciri-ciri } & \multicolumn{2}{|c|}{ berpikir tentang } & \multirow[b]{2}{*}{ keterangan } \\
\hline & & $\begin{array}{l}\text { Allah selaku mesti } \\
\text { ada, melahirkan }\end{array}$ & $\begin{array}{c}\text { Batang tubuh menjadi } \\
\text { mukim maujud, } \\
\text { melahirkan }\end{array}$ & \\
\hline 1 & $\begin{array}{l}\text { Mukim } \\
\text { maujud }\end{array}$ & Daya pikir 2 & cakrawala utama & $\begin{array}{l}\text { Setiap daya pikir } \\
\text { mengelola suatu } \\
\text { planet }\end{array}$ \\
\hline 2 & $\begin{array}{l}\text { Mukim } \\
\text { maujud }\end{array}$ & Daya pikir 3 & Bintang & \\
\hline 3 & $\begin{array}{l}\text { Mukim } \\
\text { maujud }\end{array}$ & Daya pikir 4 & Saturnus & \\
\hline 4 & $\begin{array}{l}\text { Mukim } \\
\text { maujud }\end{array}$ & Daya pikir 5 & Yupiter & \\
\hline 5 & $\begin{array}{l}\text { Mukim } \\
\text { maujud }\end{array}$ & Daya pikir 6 & Mars & \\
\hline 6 & $\begin{array}{l}\text { Mukim } \\
\text { maujud }\end{array}$ & Daya pikir 7 & Matahari & \\
\hline 7 & $\begin{array}{l}\text { Mukim } \\
\text { maujud }\end{array}$ & Daya pikir 8 & Venus & \\
\hline 8 & $\begin{array}{l}\text { Mukim } \\
\text { maujud }\end{array}$ & Daya pikir 9 & Merkurius & \\
\hline 9 & $\begin{array}{l}\text { Mukim } \\
\text { maujud }\end{array}$ & Daya pikir 10 & Bulan & \\
\hline 10 & & & $\begin{array}{c}\text { Tanah, jasad, objek } \\
\text { utama yang menjadi } \\
\text { keempat bagian yaitu } \\
\text { angin, bara, air dan } \\
\text { bumi. }\end{array}$ & $\begin{array}{l}\text { Akal kesepuluh tidak } \\
\text { lagi memancarkan } \\
\text { akal-akal berikut, } \\
\text { karena kekuatannya } \\
\text { sudah melemah. }\end{array}$ \\
\hline
\end{tabular}


Kemudian, daya pikir yang diperoleh pada roh individu (Sirajuddin, 2012). daya ini bukan berjasad melainkan berdiam pada zat, yang mana pada jiwa manusia itu sendiri telah terdapat potensi dalam dirinya. Jiwa atau ruh merupakan rohani serupa kerangka bagi tubuh. Keesaan keduanya mencorakkan keesaan sebagai kegeruhan, maksudnya setiap keduanya memiliki entitas yang berlainan dan sirnanya ruh tidak membahu jasad pada spirit. Spirit kemanusiaan diucap lewat al nafs al nathiqah bersumber dari jagat raya, sedangkan jasad berasal dari jagad khalq, konkret, berpaham, berkekuatan, dan bereaksi (Daudy, 1983). Ruh ada sebab jasad sanggup menyerapnya.

Menurut Al-farabi, ruh manusia memiliki kekuatan yakni: Pertama, kekuatan bergerak kekuatan ini yang memprovokasikan untuk berjalan, mengusahakan dan bertumbuh; kedua, kekuatan megetahui, kekuatan ini yang menyemangati untuk mencoba dan berfantasi; ketiga, kekuatan untuk berpikir, kekuatan ini yang mengajak akan berpikir ala sintesis dan praktis. Kekuatan sentesis ini ada tiga tahapan yaitu: daya potensial (al hayulany) yaitu daya yang memiliki kemampuan berpendapat maksudnya melepaskan makna-makna atau konstruksi dari materinya; daya aktual (al 'aql bi al fi'l) daya yang mampu melontarkan makna dari zatnya, dan makna itu menduga memiliki bentuk dalam daya dengan kenyataannya lain lagi dalam corak energi melainkan menujum dalam bentuk sesungguhnya; daya mustafad (al ' $q$ l al mustafad) daya yang mampu menerima sistem hanya bukan dihubungkan dengan zat dan memiliki keandalan untuk melakukan korespondensi atas daya pikir terakhir (Nasution, 1973).

Teori di atas menggambarkan bahwa akal berkuasa menaikkan secara berjenjang dari pikiran dalam tatanan kecakapan ke pikiran dalam tataan tindakan dan kesudahannya ke pikiran yang diterima. Ketika pikiran yang diterima maju ke jenjang koneksi, ide dan menginspirasi. Dalam hal ini, kapasitas pikiran yang dimiliki individu sebagai pikiran yang tersembunyi dalam dirinya. Dari mula kehadirannya untuk merancangkan lingkungan entitas. Akhirnya menjelma sebuah realitas dalam lingkungan entitas. Peralihan pikiran yang tersembunyi dalam dirinya menjelma sebuah pikiran yang realitas inilah yang kelak merealisasikan individu dari mencapai ketrampilan atas rancangan-rancangan maupun konstruksi-konstruksi universal. Faktualisasi ini terbentuk sebab pikiran berfungsi menyampaikan sinar untuk makhluk, yang akan datang menghasilkan berani mengerjakan transendental dari objek-objek yang dapat dicernakan pancaindra, lalu tercantum dalam hasrat daya pikiran manusia. kesudahannya metode transendental ini menghasilkan entitas yang jelas.

Kata akal berasal dari bahasa Arab al-aql. Dalam kamus-kamus Arab, kata 'aql itu berarti mengikat atau menahan, pengikat serban misalnya, disebut 'iqal, menahan orang dipenjara disebut aqil (Yanti, 2017). Jadi, akal merupakan entitas pikiran akan berupaya meletakkan entitas pada kedudukannya, agar terlepas dari mala petaka maupun skala pelecehan yakni menggunakan petunjuk bahwa manusia yang berdaya perlu berpikir, 
berpendapat serta mengamalkan ke kiblat yang tahkik maupun nyata dan makhluk berakal harus mempunyai prioritas tepat mengenai amal perbuatan yang dilakukannya. Dengan demikian bahwa akal itu adalah fungsi otak yang jika bekerja akan berpikir atau salah satu kerja otak adalah berpikir.

Dapat disimpulkan bahwa akal pada jenis pertama dan kedua tidak berfisik (imateri/rohani), namun di antara keduanya terdapat perbedaan yang sangat tajam. Allah swt sebagai akal adalah pencipta dan Esa semutlak-mutlaknya, dan maha sempurna. Sebagai zat yang Esa, maka objek ta'aqqulAllah lebih dari satu, sehingga atas nafsi Allah terbentuk pluraritas. Peristiwa ini berbantahan terhadap kaidah ketauhidan. Berdasarkan motif inilah Al-farabi mengungkapkan bahwasanya entitas sumber diciptakan Allah swt dari entitas yang telah ada dan diciptakan sebagai emanasi semenjak dahulu, lantaran bawaan ciptaan Allah swt ada mulai sebagai figur (tak berfaedah jika Allah dilampaui dari tiada) maka semenjak itu ia refleks menciptakan. Dari hasil ta'aqol Allah pun semata-mata. mengenai bentuk daya kedua yaitu: dayadaya yang terdapat atas emmanasi satu sampai sepuluh, daya awal satu atas elemennya, sedangkan seraya pribadinya menyimpan beragam kemampuan. la dibuat bagi Allah menjadi daya pikir, hingga tujuan ta'aqgol nya tidak tunggal, melainkan ganda yakni Allah serupa wajib maujud serta individunya menjadi mukim maujud, sudah pernah dikemukan oleh Al-farabi ada sepuluh daya pikir dan sepuluh planet. Daya pikir kesepuluh (daya pikir fa'a) selain melebihkan keaslian terhadap para utusan tuhan dan filsuf-filsuf, serta berkedudukan mengelola bumi serta seluruh semesta. Serta menduga pemikiran Al farabi mengenai planet terdorong sebab pendapat astronomi kuno tatkala mengutarakan Sembilan planet. Pada daya pikir golongan ketiga, daya pikir bagaikan daya berpikir yang ada dalam otak terdapat dalam gelora individu. Pada setiap manusia itu sendiri sudah terdapat potensi untuk berpikir. Berpikir erat kaitannya dengan otak. Karena salah satu fungsi otak adalah berpikir. Ilmu yang mempelajari otak adalah neurosains

\section{B. Otak dan akal perspektif neurosains}

Neuro berarti saraf, dan sains berarti ilmu. Neurosaian merupakan pengetahuan akan datang, pengetahuan yang derajat kompleksitasnya terlalu menantang dan memukau lantaran menumpu nalar atau otak sebagai jantung aktivitas (Taruna, 2015). Perkembangan neurosains sebagai pengetahuan mengalami kemajuan yang signifikan (Yusmaliana \& Suyadi, 2019).

Otak atau mantik membentuk mestika dari tahta jasad makhluk (Taruna, 2015). Anggota jasad tidak saja manusia, binatang pun mempunyainya. Saat pikiran bertindak dan di antara tindakan pikiran itu adalah berasumsi, bahwa otak atau mantik yang bertindak maupun berperan termaktub daya pikir. Seseorang yang tiada berakal ialah 
seseorang yang tiada memanfaatkan otaknya berguna untuk berpikir. Mantik dapat diasosiasikan dengan sifat penting perkembangan potensi otak dalam neurosains (Suyadi, 2017a). Ayat berkaitan dengan otak adalah ubun-ubun yang pada Q.S Al-Alaq [96]: 15-16. Otak atau mantik yang berkerja ditutur sebagai daya pikir inilah yang memisahkan antara manusia sama binatang melata, dan manusia sama manusia, “al insanu hayawanun nathiqun, manusia adalah hewan yang berpikir" Otak tanpa akal dia tidak akan bisa memahami begitu juga terbentang secara lisan maupun tulisan semenjak 14 dekade lihat QS. Al Anfaal [8]: 22.

Secara umum, struktur otak terdiri dari dua hemisfer (kanan dan kiri) yang mengontrol berbagai macam fungsi otak seperti: berpikir, abstraksi, dan bahasa (Taruna, 2015). Menurut Suyadi anatomi otak yang dibagi menjadi dua tersebut hanyalah otak besar atau disebut otak depan bukan keseluruhan otak itu sendiri (Suyadi, 2018b). Otak membentuk lobus, luar otak. Kemudian dibagian tengah terdapat thalamus yang meupakan gumpalan saraf sensorik dari seluruh tubuh dan transfer informasi kebagian otak lainnya (Taruna, 2015).

Pada otak dibagi menjadi tiga wilayah subbagian: otak belakang (occipital), otak tengah (parietal),dan otak depan (Frontal) (Taruna, 2015). Otak belakang terletak dibagian belakang tengkorak. Fungsi utama medulla untuk mengontrol tekanan darah, denyut jantung, dan pernapasan. Hal ini juga berisi cerebellum yang mengontrol gerakan halus seperti threading jarum. Reflex dan umpan balik juga sangat penting dari fungsi otak belakang, karena merupakan bagian dari sumsum tulang belakang; otak tengah terletak di antara otak belakang dan otak depan. Informasi dari mata, telinga dan kulit yang disampaikan melalui otak tengah. Contohnya, pada saat kepala digerakkan ke kiri maupun ke kanan, otak tengah akan memerintahkan mata untuk bergerak dengan lancar dan arah yang berlawanan, hal ini untuk menjaga mata terfokus pada objek meskipun kepala bergerak; sedangkan otak depan merupakan bagian otak yang sangat bekembang. Sinyal dari thalamus, yang berasal dari mata dan organ-organ indra lainnya ditransmisikan ke otak depan. Proses ini berperan penting dalam manajemen atau dinamika perasaan. Bagian lain dari otak depan adalah hipotalamus, seperti: rasa lapar, rasa haus, dan dorongan seks (Taruna, 2015). Dapat di lihat gambar struktur otak di bawah ini (Reece, 2008): 


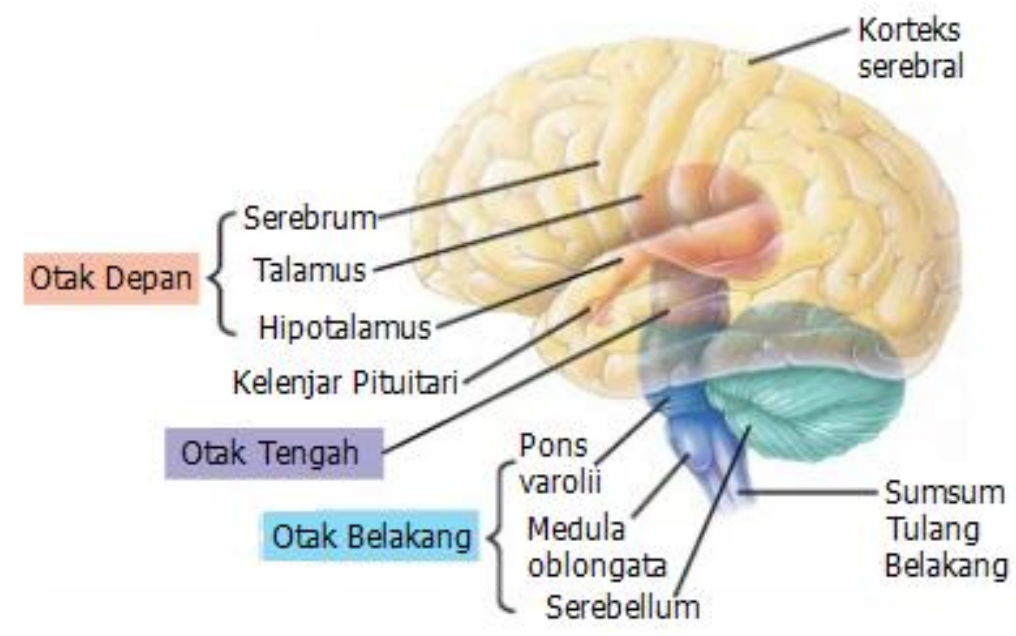

(Sumber: Campbell, et al, 2008)

Gambar 1. Bagian-bagian otak

Penalaran berproses melalui mediasi intensitas yang ada di antara penalaran yang menerima ketangkasan untuk menggapai gambaran entitas-entitas yang sering diperoleh bagi pancaindra, memulihkan entitas-entitas tersebut ke dalam pikirannya seraya menyingkat gambaran-gambaran asing dari gambaran-gambaran entitas tersebut (Fu`ad, 2018). Gambaran beberapa pegangan gambaran-gambaran disisi naluri oleh daya pikir, yang memisahkan gambaran-gambaran tersebut demi membangun gambaran lainnya (Endang, 2004).

Penjelasan yang didapatkan oleh daya pikir, dicadangkan dalam 2 susunan berupa: energi efektif maupun non efektif. Bentuk penjelasan termaktub adalah sebagai kuantitas dorongan syaraf yang ditranmisikan bagi axson perdetik (Taruna, 2015). Menurut Suyadi, ilmu saraf adalah ilmu tentang otak atau ilmu berpikir, termasuk pemikiran kritis dan kreatif, dalam upaya menghasilkan karya inovatif dan kredibel (Suyadi; Widodo, 2019).

\section{Pembelajaran neurosains dalam pendidikan Islam}

Sejauh ini, pendidikan Islam baru hanya membahas pikiran ('aql) dalam Al-Qur'an, dan belum terkait dengan otak dan ilmu saraf (neurosains). Dengan kata lain, pendidikan Islam belum membayar serius perhatian pada ilmu neurosains (Suyadi, 2019). Salah satu indikasi adalah bahwa pembelajaran agama Islam tampaknya pedagogis doktrinal, dan bukan rasional dan empris (Suyadi, 2018a). Sehingga akibatnya, pendidikan Islam belum mampu mengembangkan potensi otak yang ada pada diri peserta didik menjadi manusia yang unggul, di mana keunggulan manusia ditentukan oleh pikiran/akal atau otak mereka sendiri. 
Dalam pembelajaran neurosaians merupakan pengetahuan akan datang, sebagaimana pengetahuan tersebut jenjang kerunyamannya benar-benar menantang serta mengagumkan lantaran menyangsang otak sebagai kunci keaktifan (Taruna, 2015). Ilmu neurosains merupakan ilmu tentang proses berpikir. Penelitian dalam pendidikan Islam menggunakan interdisipliner, dan tran-disiplin telah membuat koneksi dengan ilmu saraf, ilmu tentang otak (Suyadi; Widodo, 2019). Oleh karena itu, ilmu saraf adalah "evolusi ilmiah" untuk konsep 'Aq/dalam pendidikan Islam. Tanpa neuroscience, tampaknya menjadi doktrinal pedagogis, bukan empiris rasional (Suyadi; Widodo, 2019). Sebagaimana tujuan dari pendidikan adalah untuk mengasah cara berpikir peserta didik. Pendidikan adalah sesuatu yang esensial bagi manusia. Dengan pendidikan, manusia bisa menghadapi alam semesta demi mempertahankan hidupnya. Oleh sebab itu, pendidikan Islam menempatkan pendidikan pada kedudukan yang tinggi dan penting dalam doktrinnya (Ramayulis, 2002).

Mengenai pendidikan, Al-farabi berpandangan searah pada ide-idenya akan keseluruhan pemikiran dan agama. Hal ini disebabkan ketika penyampaiannya tentang edukasi, berupa ekplisit ataupun tersugestif sering mengkaitkan celah-celah daya pikir yang menggantikan pemikiran dan keyakinan. Inilah yang selaku tanda-tanda dalam pandangan edukasi beliau.

Dalam pembelajaran, Al-farabi condong menekan atas pendirian etika dan daya pikir. Lantaran pengetahuan murni semata-mata akan dapat diperoleh melalui qolb yang murni, mestinya qolb murni semata-mata terbentuk apabila etikanya steril dari personalitas buruk. Perkara tersebut, Al-farabi mengemukan bahwasanya etika berhajad demi mencapai kebahagian sebagai haluan termulia, oleh sebab itu alamiah jika persoalan etika yang paling baik ditulis Al-farabi. Beliau menyatakan empat macam kepribadian wajib dikuasai tiap individu agar memperoleh kebahagian dunia juga alam baka. Pokok pandangan wawasan yakni keulungan gaya berpikir serta menyelidiki wawasan yang melampaui kelompok lainnya, transenden persepsi di dalam mengukuhkan sesuatu yang bermanfaat yakni keistimewaan di dalam mengelola serta mepersiapkan sesuatu yang baik, pentingnya etika ketika berpikir merupakan keistimewaan integritas sepanjang menjaga solidaritas serta tahu terhadap aturan, prinsip siasat betindak dan berupaya ialah keistimewaan gaya aktivitas di dalam seluruh bidang karir, berupa karir modus operandi maupun pabrik, dan lain-lainnya (Al-Farabi, 1982).

Teori di atas menggambarkan bahwa, di antara pandangan Al-farabi mengenai edukasi yang dijelaskan di atas, di antara pandangannya penulis berpendapat edukasi masih relevan akan dilaksanakan terhadap pendidikan Islam terkhusus di Indonesia. Apalagi pelaksanaan pandangan Al-farabi dalam teori neurosains sebagai bentuk pendidikan dalam merealisasikan pendidikan Islam yang berupaya menghadapi zaman 
modern. Selain itu penting untuk memperoleh ketertarikan dari paradigma beliau, ialah: sepadan antara daya pikir dan etika. Beliau menjelaskan kesepadanan selingan kecerdasan serta tingkah laku baik melalui pendidikan Islam, diminta berkemampuan mengembangkan daya pikir peserta didik yang tidak sekedar cendikiawan, melainkan memiliki daya pikir dengan memaksimalkan potensi akal yang ada pada dirinya.

Institusi-institusi pendidikan yang mesti memiliki paradigma yang akurat mengenai situasi tersebut, bahwasanya pendidikan produktif tidak sekedar mementingkan terhadap bagian psikologis, melainkan menumbuhkan serta memahirkan bagian berpikir pada peserta didik (Nurmuhyi, 2016). Dan ilmu saraf tidak dapat diabaikan dalam pembelajaran (Suyadi; Widodo, 2019).

Sehingga pendidikan harus bangkit dan bergerak dengan harapan menciptakan penerus suatu golongan terkhusus di Indonesia tidak sekedar cendikiawan, melainkan juga mampu mengimbangi antara akal/otak (neurosains) dalam berpikir logis sebagai contoh terhadap modernisasi pendidikan.

Selain dari itu, Al-farabi juga mengungkapkan pengetahuan yang berpatokan terhadap keunggulan jasad dapat dilihat paradigma pendidikan Islam ala Al-farabi sepertinya difokuskan terhadap peningkatan kemampuan peserta didik lebih sempurna. Persepsi jasad yang diberikan sudah termasuk IQ, EQ, SQ. Suyadi mengatakan bahwa neurosains di Amerika telah memerankan instrument strategis terhadap kosep pendidikan, terkhusus kegiatan akselarasi (Suyadi, 2012, p. 118). Oleh karena itu, pendidikan harus berorientasi kepada teori neurosains untuk meningkatkan intelektualitas jasad. Salah satu selingan strategis ialah dibutuhkan purifikasi pendidikan. Menggunakan jasad murni, mesti menggampangkan peserta didik dalam mengoptimalkan potensi otak/akal yang ada pada dirinya untuk memahami berbagai pengetahuan yang didapatkannya.

Pemikiran-pemikiran tersebut merakit dalam metode pembelajaran, sebagaimana pengajar diminta mampu mengantarkan disiplin wawasan kepada peserta didik melalui sukacita bertimbal atas substansi yang di sampaikan.

\section{KESIMPULAN}

Islam sungguh memuliakan daya pikir manusia yang terdapat dalam otaknya disebabkan kemampuan berpikir yang makin muluk bersamaan atas wawasan, inisiatif, dan kecerdasan. Hal ini juga bergandengan pada teori neurosain yang memahami mengenai akal. Keajaiban daya pikir manusia sebagai induk intelektualitas, berpikir, berkesandaran, berinovasi, juga atas fungsi otak sebagai penerjemah pancaindra. Filsuf muslim bermufakat bahwasanya daya pikir memegang tahta mulia yang terdapat dalam 
jiwa manusia. Dalam hal ini Al-farabi membagi jasad makhluk memiliki kemapuan yakni: kemampuan bergerak mampu menggerakkan demi memamah, merawat serta bertumbuh; kemampuan mengetahui mampu menyemangati berkreasi; kemampuan berpikir mampu melecut nalar menurut teoritis dan praktis. kemampuan teoritis ada 3 jenjang yaitu: daya pikir dalam diri individu memilki kemampuan berpikir bermaksud melontarkan interpretasi maupun konstruksi-konstruksi dari subjeknya; daya aktual (al'aql bi al-fi'l) akal yang telah dapat melepaskan interpretasi dari subjeknya, dan interpretasi-interpretasi mampu memiliki bentuk dalam aql tetapi kenyataannya tidak lagi dalam bentuk kemampuan melainkan dalam bentuk kenyataan; akal mustafad (al'ql al-mustafad) akal mampu menyerap bentuk bukan sekedar dihubungkan dengan subjeknya dan memiliki kemmapuan untuk membentuk koresponden terhadap daya pikir kesepuluh dan dengan akal tersebutlah otak/akal mausia terhubung dengan tuhan.

Konsep akal Al-farabi dalam teori neurosains sangat berkaiatan dengan pendidikan. Yang mana dengan konsep pendidikan, Al-farabi berpandangan searah dengan gagasannya bagi keseluruhan pemikiran dan keyakinan. Hal ini disebabkan pandangan beliau menyinggung pendidikan ekplisit maupun non ekplisit senantiasa mengkaitkan sela-sela daya pikir yang menggantikan pemikiran dan keyakinan dari daya pikir akal satu sampai kesepuluh. Selain dari itu, Al-farabi juga mengungkapkan wawasan yang berpatokani kepada keulungan jasad dapat dilihat paradigma pendidikan Islam ala Alfarabi sepertinya akan diarahkan kepada peningkatan kemampuan peserta didik supaya sempurna. Pemikiran-pemikiran yang diberikan mampu mengelola IQ, EQ, SQ. Di mana dalam mendidik harus disesuaikan dengan kemampuan berpikir peserta didik. Penelitian ini hanya sebatas deskriptif analisis isi membahas tentang konsep akal bertingkat Al-farabi dalam teori neurosains dan elevansinya dengan pendidikan Islam saja. Berdasarkan hasil penelitian tersebut peneliti berharap ada pengembangan produk kurikulum atau model pembelajran dalam teori neurosains, sehingga bisa memajukan pendidikan Islam terkhusus di Indonesia supaya bisa bersaing dengan negara-negara Barat yang telah maju dan pada umumnya seperti yang telah diterapkan pada negara Amerika yang telah menjadikan neurosains sebagai alat penting dalam perumusan pendidikan. 


\section{DAFTAR PUSTAKA}

Al-farabi. (1905). Ara Ahl al-Madinah al-fadhilah. Maktabat mathaba'at Muhammad Ali.

Al-Farabi. (1982). Tahsil al-Sa'adah. Dār al- Andalūs.

Al-Kindi. (1950). Risalah al-Kindi Fi al-Aql. Dar l-Fikr 'Arabi.

Cholik, A. A. (2015). Relasi Akal dan Hati menurut al-Ghazali. Kalimah, 13(2), 287. https://doi.org/10.21111/klm.v13i2.290

Daudy, A. (1983). Allah dan Manusia dalam Konsepsi Syekh Nuruddin ar-Raniry. Rajawali.

Endang, S. A. (2004). Wawasan Islam: Pokok-pokok Pikiran Tentang Paradigma dan Sistem Islam. Gema Insani.

Fu`ad, A. N. (2018). Otak dan akal dalam ayat-ayat neurosains. Jurnal IImiah Studi Islam, Volume. 18, 115-140.

Handayani, A. B., \& Suyadi, S. (2019). Relevansi konsep akal bertingkat Ibnu Sina dalam pendidikan Islam di era milenial. Ta'dibuna: Jurnal Pendidikan Islam, 8(2), 222240. https://doi.org/10.32832/TADIBUNA.V812.2034

Majid, F. (2002). Sejarah Filsafat Islam Sebuah Peta Kronologis (K. Musa (ed.)). Mizan Media Utama.

Muhadjir, N. (2011). Metodologi Penelitian (VI). Rake Sarasin.

Nasution, H. (1973). Filsafat Agama. Bulan Bintang.

Nukman. (2009). Mind revolution. Diva Press.

Nurmuhyi, M. A. (2016). PENDIDIKAN AKAL BUDI PERSPEKTIF AL- FĀRĀB̄̄ (Telaah Filosofis atas Pemikiran Pendidikan Al- Fārābī ). 3, 185-192.

Pasiak, T. (2006). Manajemen Kecerdasan: Memberdayakan IQ,EQ dan SQ Untuk Kesuksesan Hidup. Mizan.

Pasiak, T. (2012). Tuhan dalam Otak Manusia, Mewujudkan Kesehatan Spiritual Berdasarkan Neurosains. Mizan.

Ramayulis. (2002). Ilmu Pendidikan Islam. Kalam Mulia.

Reece, C. (2008). Biologi Edisi Kedelapan Jilid 1. Erlangga.

Simon, P. L. T. (2004). Petualangan Intelektual: konfrontasi dengan para filusuf dari zaman yunani hingga modern. Kanisius.

Sirajuddin, Z. (2012). Filsafat Islam. PT Rajagrafindo Persada.

Suyadi; Widodo, H. (2019). Millennialization of Islamic Education Based on. Qudus International Journal of Islamic Studies, 7(1), 173-202.

Suyadi. (2012). Integrasi Pendidikan Islam dan Neurosains dan Implikasinya bagi Pendidikan Dasar (PGMI). Al-Bidayah, 4(1), 111-130.

Suyadi. (2017a). Pendidikan Islam Dan Neurosains. Prosiding Konferensi Nasional Ke- 6 Asosiasi Program Pascasarjana Perguruan Tinggi Muhammadiyah 'Aisyiyah (APPPTMA), 93-107. https://doi.org/10.33367/tribakti.v25i1.162

Suyadi. (2017b). Teori Pembelajaran Anak Usia Dini Dalam Kajian Neurosains. Remaja Rosdakarya.

Suyadi. (2018a). A Genealogycal Study Of Islamic Education Science at the Faculty of IImu Tarbiyah dan Keguruan UIN Sunan Kalijaga. Al-Jami'ah: Jurnal Studi Islam, 
56 (1), 29- 58. https://doi.org/https://doi.org/10.14421/ajis.2018.561.29-58

Suyadi. (2019). Hybridization of Islamic Education and Neuroscience : Transdisciplinary Studies of ' Aql in the Quran and the Brain in Neuroscience. Dinamika IImu, 19(2), 237-249.

Suyadi, S. (2018b). Diferensiasi Otak Laki-laki dan Perempuan Guru Taman Kanak-kanak Aisyiyah Nyai Ahmad Dahlan Yogyakarta: Studi Pendidikan Islam Anak Usia Dini Perspektif Gender dan Neurosains. Sawwa: Jurnal Studi Gender, 13(2), 179. https://doi.org/10.21580/sa.v13i2.2927

Syarif. (1994). Para Filosof Muslim. Mizan.

Taruna, I. (2015). Ilmu Neurosains Modern (A. Dito (ed.)). Pustaka Pelajar.

Yanti, D. (2017). Konsep Akal dalam Perspektif Harun Nasution. Intelektualita, 6(1), 51. https://doi.org/10.19109/intelektualita.v6i1.1300

Yusmaliana, D., \& Suyadi. (2019). Pengembangan Imajinasi Kreatif Berbasis Neurosains dalam Pembelajaran Keagamaan Islam. Edukasia: Jurnal Penelitian Pendidikan Islam, 14(2), 267-296. https://doi.org/http://dx.doi.org/10.21043/edukasia. v14i2.4213 